\title{
Sexuality in the puerperium: the experience of a group of women*
}

\author{
SEXUALIDADE NO PUERPÉRIO: A EXPERIÊNCIA DE UM GRUPO DE MULHERES
}

\section{LA SEXUALIDAD EN EL PUERPERIO: EXPERIENCIA DE UN GRUPO DE MUJERES}

\author{
Natália Rejane Salim ${ }^{1}$, Dulce Maria Rosa Gualda ${ }^{2}$
}

\begin{abstract}
Puerperium is a period of great changes in women's lives, in physiological, psychological and socio-cultural terms. Female sexuality is a broad topic that should be explored vis-à-vis the singularity of woman's experiences which themselves vary at different moments in time. This article is part of the project: Sexuality in the Puerperium, the objective of which was to understand what women's experience of their sexuality is in the postpartum period. Observation and semi-structured interview were used. The research approach was qualitative and narrative was used as the conceptual and methodological method. Six primiparas who gave birth in a public hospital in São Paulo took part in the study. Observation took place in the in-patients unit in the immediate post-partum period. The interviews were conducted in the women's homes. The results of the study have enabled an understanding to be formed of the meanings and changes in sexuality during the postpartum period as well as of the experiences every woman faces in her new roles, relationships and difficulties.
\end{abstract}

\section{KEY WORDS}

Postpartum period. Sexuality.

Life change events. Women's health.

\section{RESUMO}

O puerpério é um período de grandes transformações no âmbito fisiológico, psicológico e sócio-cultural na vida da mulher. A sexualidade feminina é tema amplo, que deve ser explorado frente à singularidade de suas vivências, em diversos momentos. Este artigo é parte do projeto Sexualidade no Puerpério, que teve como objetivo compreender como as mulheres vivenciam a sexualidade nesse período. A abordagem da pesquisa foi qualitativa e a narrativa foi o elemento conceitual e metodológico, com a utilização de observação e entrevista semi-estruturada. Participaram do estudo seis prímiparas que tiveram seus partos em um hospital público de São Paulo. A observação ocorreu na unidade de internação no pós-parto imediato. As entrevistas foram realizadas nos seus domicílios. Os resultados permitiram compreender os significados e as mudanças na sexualidade durante o período, bem como as vivências de cada mulher frente aos novos papéis, aos relacionamentos e às dificuldades.

\section{DESCRITORES}

Período pós-parto.

Sexualidade.

Acontecimentos que mudam a vida.

Saúde da mulher.

\section{RESUMEN}

El puerperio es un período de grandes transformaciones en los ámbitos fisiológico, psicológico y sociocultural de la vida de la mujer. La sexualidad femenina es un tema amplio que debe ser explorado tomando en cuenta la singularidad de sus experiencias en los diversos momentos. Este artículo es parte del proyecto: Sexualidad en el Puerperio, que tuvo como objetivo comprender el modo en que las mujeres experimentan la sexualidad en el puerperio. El abordaje de la investigación fue cualitativo, y la narrativa se constituyó en el elemento conceptual y metodológico, habiéndose utilizado la observación y entrevistas semiestructuradas. Participaron del estudio seis primerizas que tuvieron sus partos en un hospital público de São Paulo, Brasil. La observación tuvo lugar en la unidad de internación en el postparto inmediato. Las entrevistas se realizaron en domicilio. Los resultados permitirán comprender los significados y cambios en la sexualidad durante el período, así como las experiencias de cada mujer frente a los nuevos roles, relaciones y dificultades.

\section{DESCRIPTORES}

Periodo de posparto. Sexualidad.

Acontecimientos que cambian la vida. Salud de la mujer.

* Extracted from a paper developed during undergraduate scientific scholarship PIBIC "Sexualidade no puerpério" School of Arts, Sciences and Humanities at the University of São Paulo. 2008. ${ }^{1}$ Undergraduate student, Course in Obstetrics, School of Arts, Sciences and Humanities at the University of São Paulo. São Paulo, SP, Brazil. jenat@usp.br ${ }^{2}$ Obstetrical Nurse. Full professor, University of São Paulo, Department of Maternal and Child Health and Psychiatric Nursing. drgualda@usp.br

$\begin{aligned} \text { Rev Esc Enferm USP } & \text { Received: } 06 / 05 / 2009 \\ 2010 ; 44(4): 888-95 & \text { Approved: } 12 / 03 / 2009\end{aligned}$




\section{INTRODUÇÃO}

The puerperium is the period that begins after birth, and is marked by changes, the purposes of which are to restore the mother's organism to the non-pregnant state. These transformations occur not only in physiological, endocrinal and genital terms, but to the woman as a whole person $^{(1)}$.

It is known that pregnancy and the puerperium are periods in the life of women that need special attention for during this time, many physical, hormonal and psychological changes occur and those to do with social participation are involved, all of which reflect directly on women's health ${ }^{(1)}$

The puerperium starts one to two hours after the expulsion of the placenta. Its end is not fixed, for in the breastfeeding period, the mother's organism continues to undergo a process of modification and the return of menstrual cycles is highly variable ${ }^{(1)}$. It is worth stressing that the type of delivery and any complications arising can have a direct influence on the post-partum period.

One of the aspects to be considered is the possibility of perineal trauma which can be spontaneous on account of lacerations or ruptures caused by the passage of the fetus along the birth canal, or when an episiotomy is performed. Currently the rates of such occurrences are low for women who undergo labor with the perineum remaining intact ${ }^{(2-3)}$.

Episiotomy is a surgical incision performed in the perineum before the expulsion of the head of the fetus, and is performed with scissors or a scalpel. The incision requires later surgical repair ${ }^{(4)}$. Recommending an episiotomy is associated with signs of fetal distress, the insufficiency of labor, the threat of third-degree laceration and/or a history of third degree laceration in a previous birth ${ }^{(5)}$. The routine use of episiotomy has long been advocated to protect the perineum from more serious injuries, but currently it is not considered a good practice, for its use is related to higher rates of perineal trauma, and can cause pain and bleeding. According to scientific evidence, performing episiotomy as a routine does not protect the vaginal structures, but rather causes them harm ${ }^{(6)}$

Post-natal perineal pain is a problem that affects many women and may adversely affect maternity and initial sexual experiences, thereby directly interfering in the sexuality of women during this period. Many women in the post-partum period do not feel ready for the resumption of sexual activity due to perineal injury, even though many are obliged to return to sexual activity because of pressure from their partner ${ }^{(7)}$.

Authors differ as to the most opportune time to resume sexual relations during the puerperium. There are authors who say that coitus can be resumed two weeks after giving birth, depending on the woman's feeling of well-being. This is despite the fact that resuming sexual relations prematurely can bring discomfort and pain due to uterine involution and incomplete healing of the scars from episiotomy and lacerations. Others claim that the return to sexual activity should occur only after thirty days because of discomfort and to allow time for healing ${ }^{(3)}$.

A study carried out by means of a meta-analysis of 59 research studies published in English and German between 1950 and 1996 concluded that 40\% of women have problems in their first sexual relationship after childbirth. More than half of them have painful experiences during intercourse after a birth. This study also showed that $57 \%$ of women were dissatisfied in regard to giving sexual pleasure to their husbands and that, in most cases, what motivates women to resume their sexual life after childbirth is the need to satisfy their partner. The study asserts that sexual activity, both during pregnancy and post-partum, is more intense when women are free of discomfort such as pain and vaginal bleeding ${ }^{(8)}$.

The experience of sexuality in the postpartum period is, therefore, very complex as a result of modifications in the biological, psychological and social factors. Moreover, it is important to understand the perception of women concerning their sexuality in the postpartum period, since both the woman and her partner may experience difficulties for a certain period. It is essential to understand and take into account both the physiological modifications and the transformations in the social, psychological, and family environments.

occur during the postpartum period are widely known. However, what women's experiences and feelings are, as well as how they deal with these changes, all of which are related to their subjectivity and their perception of their own bodies, needs new insights so that quality care can be given to women in this period. These considerations demand more detailed and focused research on the topic.

\section{OBJECTIVE}

The objective of the study was: to understand what women's experience of their sexuality is in the postpartum period.

\section{METHOD}

The basic assumption of the study is that meaning and knowledge always have, as a reference, the world which takes shape out of human experience, and is formulated and learned by means of distinct symbolic forms and inter- 
pretative practices. The body is a reflection of society, and it is not possible to conceive of its processes as being exclusively biological. Feelings and practices are applied to the bodies that are at the base of social life.

Based on this premise, this study was designed in order to take a qualitative approach. Qualitative research seeks to find responses to particular issues. It works within the universe of meanings, motives, aspirations, beliefs, values and attitudes, which refer to a deeper area of relationships, processes and phenomena ${ }^{(9)}$. Under this qualitative approach, narrative is used as a conceptual and methodological element. Narrative presents itself as a possibility for understanding and communicating subjective human experiences related to the objective reality of the body. It emphasizes meaning, the process of producing histories, the relationships between the storyteller and the other subjects, the processes of knowledge and the multiplicity of forms in order to capture and comprehend experiences ${ }^{(10)}$.

The narratives can be obtained in different ways, the means most often used being the technique of an open interview with prompting questions, that is, approaches that lead the person to recount how a given fact happened or to narrate their experience. Another way to obtain narratives is by observation or participating observation. The dialogue between people in groups of people in a family is captured by the researcher, together with the observation of how these accounts interfere in their daily lives and how they are used as a reference for the analyses of other experiences. In this study, both were used to ascertain the experience of women ${ }^{(11)}$.

As per the inclusion criteria, the sample consisted of six women who had had one single pregnancy and were in the puerperal period, and whose delivery had been normal, independently of their reporting of perineal trauma.

The first contacts with the women were at the Centre for Normal Childbirth of the Hospital Amador Aguiar and Maternity Unit in Osasco, in the state of São Paulo. This institution has an agreement with the Brazilian Health System (SUS) and it is the only health institution which offers humanized maternity care and has an average of 600 deliveries a month. The clients are low income women, the great majority of whom live in the metropolitan area.

Observation occurred in the immediate post-partum period, while women were hospitalized. We sought to follow their cases in the post-partum care unit in order to learn of their experiences in relation to childbirth and postpartum, and how they behaved and reacted vis-à-vis the stimuli or situations pertinent at that time in order to verify the feasibility of conducting the interview. After this first contact in the puerperium unit, an interview with each of the women was scheduled at a place and time of convenience to them. The interviews took place in their homes during the remote puerperium period, that is, after the forty-third day of the postpartum.
The interviews were guided by the following questions:

- Have you have already resumed sexual activity? What has your sexual activity been like?

- Do you think a woman can have sexual activity soon after birth? How long after child-birth before it may resume?

- If you have resumed sexual activity, was it by your choice or your partner's, or did you both agree to this?

The remaining topics were based on their statements which were given freely i.e. without being prompted.

The research project was approved by the Committee for Ethics in Research (CEP in Port.) of the School of Nursing, University of São Paulo (Case No. 703/2007/CEP-EEUSP), and met the requirements of Resolution 196/1996 of the National Health Council. Authorization and consent to conduct the study were requested from the Board of the hospital. The women were informed about the purpose of the research and that interviews would be recorded. A guarantee was given that their identities would be preserved, and that their participation in research would be facilitated, without refusal leading to any adverse consequence. All of the women signed an agreement in which they gave their free and fully-informed consent to the interview.

After data collection, the interviews were transcribed and transformed into discourses. The content of the interviews was then submitted to Thematic Analysis, which "consists of discovering the units of meaning that make up a communication, whose presence or frequency means something for the analytic objective that is aimed at"(9) and resulted in three categories, namely, modifications, sexuality and communication all relating to the puerperium period. In this article, data referring to the category of sexuality in the puerperium from the perspective of the women are addressed.

\section{RESULTS}

In the category of sexuality, the women's statements make it possible to learn of the experiences that they had after giving birth regarding their sexual lives, their own bodies, and their relationships with their partners. The subcategories were: the time they waited before resuming sexual activity after childbirth; their sexual experience after delivery; their partner's behavior prior to the resumption of sexual activity; and the feelings and sensations that are present in the sexual lives of women after delivery which are linked to fear, pain and discomfort and worries. These subcategories are presented as follows.

\section{Time until sexual activity resumes}

The timing of the resumption of sexual activity during the puerperium period has been reported as an important and relevant factor for women. Pregnancy and childbirth 
involve bodily changes. Thus the time at which the body returns to its pre-pregnancy state becomes important to women. Some women said the reason for waiting was related to sources of external information, as the statements below show, the sources being television and the doctor:

I think we have to hang on a bit, to get back to it very quickly is no good. I heard on television that the uterus takes three months to return to its place (E1).

I think you have to wait for 40 days because I felt that my uterus was still open, so not everything had got back to normal (E6).

However, it can be observed in the reports from the women that the most important factor for them in the waiting period before resuming sexual activity is to respect my own body clock, the private physical and emotional wellbeing of each of them that is related to their being aware of their subjectivity and their own body.

Despite not being aware of the technical physiological functioning of her body, this woman knows that her body has changed and so, after delivery, she should respect her own body clock with regard to re-starting sexual life:

I think a woman needs a break after the delivery. I think she has to respect the timing of her body [...] I think the body is not ready, everything has its time, I don't know how much, I don't understand that bit. You have to wait for the body to say it's time, I myself think it is because, for the women, that was all quite an experience, everything was new! So I think I have to wait a bit (E2).

In this context we can say that there is no set and fixed time for resuming sexual life; every woman knows her body clock, and knows when she is ready to resume sexual activity.

I think it depends on each woman! There are women who do it even before the 40 days are up. I guess it depends on how each thinks, psychologically, I think it's just a question of time, with there being a time for going about settling down to it again (E5).

\section{Sexual experience}

In the following statements, the women talked about their first sexual experiences that they had after delivery:

A messy business. It was only once after the delivery that I plucked up courage, it was horrible, it was horrible (E5).

I think after I had her, we did it just five times. Our sexual activity went down a lot, I miss it because there is a difference, we did it a lot at the very beginning of pregnancy and now we hardly do it all (E3).

Although the above statements show that for the women, their sexual experience was not so good after giving birth, for this woman it was different, better than before:

It was better, it was more fun, because everything changes,

it is different and there is no obvious explanation, because of the milk, before the baby came along nothing came out but now it does, there are lots of new things, the sensation is different (E6).

\section{The partner's behavior before resuming sexual activity}

In the statements below, the partners wanted to have sex before the women felt ready and wanted it themselves.

In this statement, we can see that in spite of wanting to have sex, the partner understood the woman:

He was after it, as far as he was concerned, it could already have happened. He asked me for it after 20 days, then I said that it was not on, and he understood (E4).

For this woman, her partner wanted to have sex and she did not. She relates this desire to the fact that he is a man and therefore always wants to have sex.

He was all for it before me, I was indifferent to it. He wants it all the time, it's sad that men are like that (E5).

This woman says she had to keep out of her partner's way and the strategy she used was to lock herself in. He wanted to have sex before she did and he said he would not put up with not having sex.

He wanted to before me, there were days when I would go to the living room because he said he would not put up with doing without and I said that he would just have to and that was it. I locked myself in the room and shortly later he called me saying that the baby wants nursing, but it wasn't her time to be breastfed and so I ignored him. By the $15^{\text {th }}$ or $20^{\text {th }}$ day, he already wanted it and he said I could do it, and I said I couldn't and that he had to wait for 40 days because my uterus was still open (E6).

The statements below show that despite their husbands wanting sex, the men were also afraid.

He wanted to but he was scared too, it was until much later on that he came to me looking for it (E1).

In this woman's statement, her partner's fear is associated with the fact that he witnessed the birth and because he was afraid he would hurt her.

He respected me, sometimes he lay down with me and said: you still can't [...] He said he was afraid to hurt me because he'd seen everything, had watched everything. So he was a little scared, but later it was normal (E2).

\section{Feelings and sensations which involve sexual activity after child-birth: Fear; Worry; Pain and discomfort.}

\section{Fear}

It is important to say that all women who took part in this research had stitches in the perineal region. Fear was present in the return to sexual activity for these women and was shown to be associated with the external healing of the perineal regional that had been sewn up, internal 
uterine healing, with the possible pain during the first sexual encounter and also with the possibility of a new pregnancy.

I had not yet started, I was afraid [...] it seems that there is a stitch up here, it's weird, I had seen it, but I had my doubts, but I thought: I didn't have that. We had a go and it bled, it was on a Sunday that I had had a go, it bled, I was scared to death, I cried, I was scared, he calmed me down (E4).

These women show they were afraid with regard to the healing and internal repair, which they were not able to see and so could not tell if it was healing, while they could tell with the external stitches because they could see them.

I was scared of the stitches because the one outside dried up, but what about those on the inside? I was afraid it would come loose, but I think it was something in my head, but then again afterwards it was normal, it was great (E2).

In this woman's statement, fear of looking at the perineal region arose due to the grandmother of a friend who said she could not look in the mirror, even though she thought this was not true, she was still in doubt, but decided to have a look:

I was afraid to look at the stitches, I looked a lot after [...] the grandmother of a friend of mine said she could not look in the mirror when she had had stitches, I think this is nonsense. It is nonsense, isn't it? So I took a good look (E1).

The story of the girlfriends regarding their first sexual activity after the delivery has made these two women feel afraid of resuming their sex lives, this fear being associated with pain that her friends felt:

I was afraid to get on with it, because my friend said that she went through horrors, that the pain was terrible. I was afraid. I kept out of his way (E3).

I was afraid it would be horrible, because my friend said the first time was very bad, but I think the will of both us was greater (E3).

The fear of getting pregnant was also present in the sexual life of the women as we can see from their statements below:

I think I was more afraid of becoming pregnant again because I felt no pain as such. I went to the doctor, she did the test of touch and everything and it did not hurt, I'm really afraid of getting pregnant again (E5).

In this woman's statement, the possibility of getting pregnant again brought changes in the sexual life of the couple. The relationship became more fun while it was clear from what she said that she was afraid and apprehensive about becoming pregnant again even though contraceptive methods were being used. The experience that the friend had was the cause of this woman fearing another pregnancy as she already had a new-born baby to look after.

It was more fun because we are afraid, also, we are apprehensive about having another baby, even though we use condoms and I take medicine, we are apprehensive about having another new-born baby. I was afraid of getting pregnant again because I had a friend who did not wait long enough so while she was breast-feeding, she was bearing another baby inside her so I got very scared (E6).

The couple has been using condoms since the birth of their child even although they do not like doing so, for they know it was when they stopped using them that the pregnancy happened.

We've been using condoms, he doesn't like using them. At the start, we did it with condoms, but he didn't like doing so we didn't use them and so I became pregnant (E3).

\section{Worry}

The worries present in the sexual life of these women were related to the care that babies require, to the presence of the baby in the bedroom during sex and to satisfying the partner.

In this woman's statement, you can see that she gives priority to looking after the baby and only thereafter to having sex with her companion. During intercourse, if she hears the baby crying she gives it her mobile phone as a tactic to distract her baby girl until she falls asleep again.

\begin{abstract}
So we do it after she falls asleep, during intercourse, if she stirs, I pick up the mobile phone to distract her. The two of us get worried when she grunts but she soon goes back to sleep. She is a tiny tot, first I look after her, change her, put her to my breast then she falls asleep, she'll sleep for almost $21 / 2$ hours so I talk to him, she is fine, she is soon fast asleep! (E2).
\end{abstract}

The presence of the baby in the bedroom during sexual intercourse is a cause for concern. In the statement below, the fact of having sex in the same room as the one in which the baby sleeps, means lack of respect for the child. During pregnancy, this woman was unable to have sex for the same reason.

The baby sleeps with us and I think that is horrible, I think it the pits, I think it shows a lack of respect for him, I don't know if it's something to do with my brain, even during pregnancy I was embarrassed to do it because he was there. Even knowing it was good to do if I were to have a normal delivery, I was afraid to do so. However I did it but it was only he who finished off because I couldn't do so, up to 4 months, it was normal, after the fifth month I stopped, I only did it for his sake but it was he who came as I couldn't, as I couldn't concentrate [...] I think of him, I wouldn't like it if my parents did this to me (E5).

In this statement, the presence of the baby also worries the woman during sex, she is worried about the possibility of waking up her daughter. She also spoke about pregnancy; she couldn't have intercourse because it seemed that the baby was in the midst of the activity.

At first I was apprehensive, I spoke to him - the baby is here - and he said - no, she won't wake up and I insisted she will - I go, I have the feeling that she'll wake up and 
you'd like to ignore her - look here, I don't know what more I can do. I was worried because she might wake up. In the nine months we stopped having sex, it was not on, it seemed that she was in the middle (E6).

These women were worried about satisfying their partner, in knowing whether intercourse was like it was before the baby was born, if the perineal region continued to be like it was before.

I asked if I was wider, he said no, said it was normal. He just told me that I was really dry so I bought lubricant because what we had, had been unsuccessful (E5).

In this woman's statement, the feeling of shame in talking about this subject with her partner appears:

I was ashamed to ask him if it was good for him, so I asked: Is it normally tight? Then he said it was normal. So I said, are you sure it continues to be good? He said: it continues to be marvelous, you are the woman I love. He is very sincere, I think if doing it was not good, he would say so (E2).

\section{Pain and Discomfort}

Pains and discomfort during intercourse were associated with the stitches and healing of the perineal region after delivery. It can be determined that episiotomy was performed frequently, and this practice had consequences for the women's sexual life. Perineal protection during normal delivery is recommended. It is also important to stress that very often the women who undergo episiotomies are not told of the incision, they do not know the reason for the incision being made nor of the consequences and after-care.

It is because it feels like I'm being scratched, anyway we had a go then it bled, it was Sunday I tried to do it but it hurt, it bled (E1).

... so he was patient, but it hurt a little. The cut was on one side and I felt pain on the other side, sort of a scratching on the other side so I don't know why I thought that it should have hurt on the side the stitches were on but it didn't. I only feel pain on the other side, not where the stitches are (E2).

In the case of this woman besides having problems with the stitches she also had some because of the lack of lubrication:

[...] because there is zero lubrication I don't know if it's just me or if this is normal. I thought I had an internal stitch, because I felt something bothering me in here I think the ones inside messed it up, bothered me, because you can feel them, you know (E5).

The women reported discomfort in relation to the presence of breast milk during sex. In these statements, it can be seen this disgusted them and they did not like the presence of milk. On the contrary, their companions did not mind the presence of milk and wanted to touch their breasts and try the milk. In the women's opinion their partners' behavior is strange and does not seem normal. For them, their breasts and the milk now have a nutritional character for the baby and therefore they should not have a role to play in intercourse.

He takes the contrary view. It's me who doesn't like it because the milk leaks out so he says to me : no problem, because I want to touch you, but that's disgusting I say, then he quarrels with me: don't say it's disgusting; it's the milk for the baby, but I think that thinking like this is a little strange; I do not like it because the milk spurts out (E2).

\section{DISCUSSION}

The birth of a child can be considered an event of great impact for a woman in different facets of her life. The modifications of a bodily and hormonal order that occur during the postpartum period are experienced by women not only at the physical level but also in terms of feelings, in the way they look at themselves and how they make relationships in society.

The way that each woman deals with these changes is related to subjectivity and the perception of their own body and of themselves. Sexuality is integrated with this new process that women experience, whether with regard to themselves, to their body and femininity or to life experiences with their partner. The depth of sexuality is often not disclosed, there are signs that cultural and social construction lead to the uniqueness with which each person experiences their sexuality, and with being in the world ${ }^{(12)}$.

In this study, the timing of starting sexual activity during the puerperium has been reported as an important and relevant factor for women, mainly due to the presence of stitches, the fear of pain and bleeding. Most information found in the literature regarding women's return to sexual life in the puerperium period says this return should occur from the fortythird day post-partum. The reason for prioritizing this waiting period is related to uterine involution and healing from the episiotomy and lacerations. Even if they are not visible, they may have occurred at any point throughout the birth channel. Others consider that waiting for two weeks after birth is sufficient and that sexual activity can be resumed in accordance with the comfort and desire of the woman ${ }^{(3)}$.

The women said they knew, from several sources of information, about the timing of resuming sexual activity, but what was more evident is that every woman's organism takes its own time, and each woman has to respect her body clock. Only one of them reported pressure from her husband to resume sexual activities, but she found strategies to circumvent the situation.

The women who participated in this study had spontaneous lacerations or an episiotomy and reported pain, discomfort, and difficulty in sexual intercourse. They also reported that the mere presence of the stitches inhibited them from resuming sexual activities.

Dyspareunia, the pain during sexual intercourse, was reported in a negative way in terms of female sexuality 
because it adversely affected both sexual health and having intercourse, thus causing women to be dissatisfied ${ }^{(13)}$. This problem can also be related to gynecological diseases, infections, and hormonal disturbances. Post-natal perineal pain is a distressing problem that can negatively affect a woman's life and her experiences of motherhood ${ }^{(14)}$.

Another aspect reported was the lack of vaginal lubrication. During the puerperium this may occur due to atrophy of the vaginal epithelium on account of the increase in prolactin, which causes suppression in ovarian activity and therefore decreases progesterone and estrogen levels ${ }^{(7)}$.

Fears were also feelings present in sexual activity during the puerperium and largely related to pain. Fear of pain was reported as arising from unsuccessful attempts or reports of people whom they knew well who had undergone a negative experience.

It can be observed, therefore, that there is a lack of taking a broad look at the sexuality of women in the postpartum period on the part of professionals in obstetric care. What is becoming essential to the practice of protecting the perineum and is of fundamental importance for women to know, is what episiotomy is, when it is recommended and its consequences ${ }^{(15)}$.

In some of the statements, women's concern during sexual intercourse can be seen to be about looking after the baby and the fear that it might wake up. One of the interviewees said that before she has sex she does everything that is pertinent to taking care of the baby and waits till he falls asleep. They pointed out worries vis-à-vis the baby's presence in the room during sexual intercourse. This concern appeared in the statement of one of the women as showing disrespect for the baby. The fact that the baby is present at the time of intercourse bothers her even if it is sleeping. You can see then that for her, the baby is a sensitive being who has the ability to perceive and should not witness the sexual relationship of its parents, for this is pertinent to the adult phase of life.

The ejection of milk during the sexual act was also reported as a discomfort. The milk represents the maternal role and seems to interfere in the performance of the female role. In different cultures and societies, different values are attributed to the female breast. During maternity, the female breast, which has very often only been seen as an erotic symbol and source of pleasure, becomes a sacred symbol that is the source of food and life ${ }^{(16)}$. The female breast, therefore, goes beyond the biological conception and gains multiple socio/cultural senses by means of an anthropological vision.

It is understandable that during sexual relations, the woman wants to be just herself, and to switch off her maternal functions ${ }^{(7)}$. However, it is possible to verify that the maternal role has an influence on sexual relationships, for there are worries about the baby and how best to look after it. Another fact that deserves emphasis is in regard to preventing a new pregnancy. Women referred to their fear of pregnancy and pondered the difficulty about the use of condoms. Other contraceptive methods can be used and these possibilities can be discussed and offered to couples, before a new pregnancy occurs.

Thus it can be observed that multiple factors of a physical and mental order are involved in the sexuality of women during the puerperal period: the experiences of each woman, their values and relationships are associated with the way that each woman deals with sexuality during the puerperium.

\section{FINAL CONSIDERATIONS}

How women should be regarded during the puerperium should be presented in a broad way, by listening to their difficulties and experiences, getting to know the cultural and social context in which they live so that caring for them is conducted effectively. Puerperal consultations are generally held after 40 days, the period during which the woman and her family undergo the most difficult phase of adaptation. Consideration should be given to the possibility of a return from the premature puerperium and to sources of access, should difficulties arise, and these should be cleared up immediately. Prior guidance given in prenatal care can be an important source of information and help in facing the difficulties that may occur. The involvement of the companion in providing care has many positive aspects and he may become an important source of support and assistance.

Qualitative narrative research was of fundamental importance in facilitating learning of the women's experiences in relation to such an intimate issue in the life of each of them. Research studies using this approach with regard to sexuality in the puerperium, from the perspective of the whole family, should be conducted to deepen understanding of how women experience this period in order to intervene effectively when necessary so as to foster adequate solutions to possible difficulties.

\section{REFERENCES}

1. Brasil. Ministério da Saúde. Secretaria de Políticas de Saúde. Área Técnica de Saúde da Mulher. Parto, aborto e puerpério: assistência humanizada à mulher. Brasília; 2001.
2. Camacho RS, Cantinelli FS, Ribeiro CS, Cantilino A, Gonsales $B K$, Braguittoni E, et al. Transtornos psiquiátricos na gestação e no puerpério: classificação, diagnóstico e tratamento. Rev Psiq Clin. 2006;33(2):92-102. 
3. Cunningham FG, MacDonald PC, Gant NF, Leveno KJ, Gilstrap LC, Hankins GDV, et al. Williams obstetrícia. 20a ed. Rio de Janeiro: Guanabara Koogan; 2000. O puerpério; p. 465-75.

4. Ziegel EE, Cranley MS. Enfermagem obstétrica. 8a ed. Rio de Janeiro: Guanabara Koogan; 1985. Assistência da enfermagem durante o parto; p. 382-408.

5. Organização Mundial da Saúde (OMS). Assistência ao parto normal: um guia prático. Brasília: Ministério da Saúde; 1996.

6. Diniz SG, Chacham AS. O "corte por cima" e o "corte por baixo": o abuso de cesáreas e episiotomias em São Paulo. Questões Saúde Reprod. 2006;(1):80-91.

7. Abuchaim ESV. Vivenciando a amamentação e a sexualidade na maternidade: "dividindo-se entre ser mãe e mulher" [tese]. São Paulo: Escola de Enfermagem, Universidade de São Paulo; 2005.

8. von Sydow K. Sexuality during pregnancy and after childbirth: a metacontent analysis of 59 studies. J Psychosom Res. 1999;47(1):27-49.

9. Minayo MCS. Pesquisa social: teoria, método e criatividade. 25a ed. Petrópolis: Vozes; 2007. O desafio da pesquisa social; p. 9-29.
10. Mattingly C, Garro LC. Narrative representations of illness and healing: introduction. Soc Sci Med. 1994;38(6):771-4.

11. Silva DGV, Trentini M. Narrativas como técnica de pesquisa em enfermagem. Rev Lat Am Enferm. 2002;10(3):423-32.

12. Ressel LB, Gualda DMR. A sexualidade como uma construção cultural: reflexões sobre preconceitos e mitos inerentes a um grupo de mulheres rurais. Rev Esc Enferm USP. 2003; 37(3):82-7.

13. Gerin L. A ocorrência de dispareunia entre mulheres: como fica a saúde sexual? [tese]. Ribeirão Preto: Escola de Enfermagem de Ribeirão Preto, Universidade de São Paulo; 2008.

14. Enkin WM, Marc JNC, Keirse JP. Guia para atenção efetiva na gravidez e no parto. 3a ed. Rio de Janeiro: Guanabara Koogan; 2005. Dor e desconforto perineais; p.243-247.

15. Previatti FJ, Souza VK. Episiotomia: em foco a visão de muIheres. Rev Bras Enferm. 2007;60(2):197-201.

16. Pereira GS. Amamentação e sexualidade. Estudos Feministas. 2003;11(2):467-91. 